\title{
Scholastic Assessment of Insurance Productiveness from the Marketing Perspective
}

\author{
Samuel Affran
}

\begin{abstract}
The Ghanaian insurance industry is on "life supporting machine" finding it very difficult to attract potential customers to patronize their services. Existing customers are also not loyal at all the reasons am yet to unravel. Individuals as well as organizations lack the interest of investing their scares resources in the insurance industry. Thus managers in this spectrum have to make it a point to constantly seek new ways to improve their services with the strategic intent of "loyalising" the hard won customers. It's in the light of this that, this study is undertaken to examine whether relationship marketing strategies can be one of the assured ways of developing loyal customers. Again to ascertain how trust influence these relationship marketing strategies and customer loyalty. The population of the study is of some section of insurance subscribers in the greater Accra and central regional part of Ghana. Hypotheses of the study were analyzed using correlation and hierarchical regression analysis. Selfadministered questionnaires were distributed to respondents. The researcher theorizes and investigates that there is high positive correlation between the four underlying constructs of relationship marketing and customer loyalty. The results of this study again indicated that all the independent variables (communication, competence, commitment and bonding) have a positive significant impact on (dependent variable) customer loyalty through trust as the mediating variable. Managers are to note that the propensity to create customer loyalty depends on the level of trust they have built with its customers. Thus, the focus should be on investing in the customer's trust which will subsequently lead to customer loyalty. Management of insurance services are to note that the findings provides a more reliable and empirical measure for describing and evaluating the level of their customer loyal with the services they deliver. It again provides empirical support for strategic decisions in several critical areas of their operations, and above all, provides a justifiably valid and reliable guide for designing workable relationship marketing strategies for creating loyal customers. Originality of this study is proven because it has empirically refined the body of knowledge relating to customer loyalty in the Ghanaian insurance industries.
\end{abstract}

Index Terms-Relationship Marketing Strategies, Customer Loyalty, Trust, Insurance Industry, Ghana.

\section{INTRODUCTION}

Within a space of seven months five Ghanaian owned Banks have collapsed and they have no one to resuscitate them and not even the insurance industry ventured. Investors as well as employees in the banking sector lost millions of dollars just because their activities were not insured. All because of the fact that the Ghanaian insurance industry has lost their credibility woefully thus other corporate

Published on December 20, 2019

S. Affran is with the Department of Marketing, Procurement and Supply Chain Management, University of Education Business School, Winneba Ghana. (e-mail: samuelaffran77@gmail.com) institutions does not see the need to do business with them. The opposite is the truth in the western world. The industry is not appealing at all and a critical example is where drivers were seriously looking for an alternative for third party insurance simply because they were fed-up with their services. Greater majorities of the Ghanaian populace have less interest in this sector and what is worsening the case is that managers are not doing much to attract and retain their customers. Testimonies emanating from customers concerning claims and its associated interest are nothing to talk about. A very bad word of mouth is making the industry suffer in this part of the world. Business entities as well as individuals do not see the need to lock up their monies with the insurance companies. There are a lot of erroneous impressions against the industry making it very difficult to compete for customers with other firms within the financial industry. The few they are able to attract; they are unable to retain. Thus loyalty has become a very scares commodity in the industry. The question then is how can the insurance companies build and maintain loyal customers? An answer am yet to provide with empirical evidence using relationship marketing as the ore. Developing a sound managerial strategy for retaining hard won customers will be one of the obvious antidotes for attaining competitive advantage. In other words, an insurance company that wants to be more competitive should gear its entire relationship marketing effort in attaining customer loyalty. Bose (2002) posits that it is becoming evident that companies have to modify fundamentally the way in which marketing is done, i.e. a shift from managing a big pool of clients to managing specific customer base. The aim of this research is to empirically investigate the relationship and the impact that exist among relationship marketing strategies, trust and customer loyalty in the Ghanaian insurance industry. Specifically, the objectives of the study are to: Investigate direct relationship between relationship marketing and customer loyalty and also to examine the impact of trust on relationship marketing strategies and customer loyalty. To achieve these objectives, the research is guided by the following questions: Does relationship marketing strategies influence customer loyalty positively? What is the impact of trust on relationship marketing strategies and customer loyalty?

\section{MARKet TRENDS IN GHANA's INSURANCE INDUSTRY}

Insurance penetration is still very low in the country. Insurance penetration, which is defined as the contribution of total insurance premiums to Gross Domestic Product (GDP) is still less than $2 \%$. Conscious efforts are being made to improve the penetration through the encouragement 
and development of micro insurance as well as the enforcement of compulsory insurances in the country. Industry gross premium amounted to GHC 1,929million at year end 2016. This represents a growth of $24 \%$ from GHC1, 560 million over the same period in 2015. Total premium for life insurance stood at GHC $859 \mathrm{~m}$ while nonlife business amounted to GHC 1070m. This represented a contribution of $45 \%$ and $55 \%$ respectively in 2016 compares with a similar contribution of $45 \%$ and $55 \%$ in 2015 . A total of fourteen (14) companies were licensed in 2016. One (1) Life, two (2) Non-Life companies, one (1) Loss Adjuster, and ten (10) Broking companies. The year ended with twenty-seven (27) Non-life, twenty-four (24) Life, three (3) Reinsurance and seventy-eight (78) Broking companies. The 2 non-life companies were Loyalty Insurance Company Limited, located within the Shippers 'Authority building in Accra, and Multi Insurance Company Limited, with its head office in Kumasi. African Life Assurance Limited was also licensed within the year. I AM Loss Adjusters \& Surveyors Ghana Limited was the second loss adjusting company to be licensed since the inception of the Insurance Act, 2006 (Act724). The ten (10) new entrants to the broking sector are listed below: i. Insurance Management Services Limited ii. Worldwide Insurance Brokers Limited iii. IRisk Management Limited iv. Risk Partners Limited v. Pacific Insurance Brokers Limited vi. Strategic Insurance Consult Limited vii. Anchor Premier Brokerage Limited viii. Ideal Insurance Brokers Limited ix. K \& A Insurance Brokers Limited x. Supreme Trust Insurance Brokers Limited. The National Insurance Commission also approved a merger between Regency Alliance Insurance Limited and Nem Insurance Ghana Limited to form Regency Nem Insurance Ghana Limited. The Company's equity is owned $60 \%$ and $40 \%$ between Regency Alliance and Nem Insurance respectively. Aggregate insurance industry assets stood at GHS 3.76bn as at the end of 2016, representing a growth of $23 \%$ from GHS 3.06bn in the prior year. Life's contribution to total industry assets was GHS 2.25 bn representing $60 \%$ as against Non-life's contribution of GHS $1.51 \mathrm{bn}$ representing 40\% (National Insurance Commission- annual report 2016).

\section{EMPIRICAL ANTECEDENCE OF RELATIONSHIP MARKETING STRATEGIES}

Du Plessis (2010:88) defines trust as follows: "Trust refers to one party believing that the other party will act in his best interest, that the other party is credible and that the other party has the necessary experience. Credibility is viewed as a hallmark of trust. Credible customer is willing to stay with a business entity irrespective of better alternative offered by a competitor. (Aydin \& Ozer, 2005:146) opinioned that specifically, trust reduces the uncertainty in an environment where customers feel vulnerable. Thus, trust is a necessary ingredient in determining customer commitment to a particular product. The degree of trust exhibited by one party will to large extent affect the other party behavioral patterns. Trusting a product or service means forming a positive inclination towards such product or service. Barry (2004) posit that, stable quality of product, sufficiency and benevolence are the determinants of customers' trust. John Simon and Minor
Michel (2003) stated that satisfaction is the prerequisite of trust; they saw satisfaction as the bedrock of trust. Hennig Thurau and Klee (1997) argued that, trust plays an imperative role in repurchasing which was supported by (Bart et al., 2005) findings show a positive relationship between trust and behavioural intent. In this study trust means Faith of customers that company and retailer is honest with them.

Ibrahim and Najjar (2008:14) define commitment as "an exchange partner believing that an ongoing relationship with another is so important as to warrant maximum efforts at maintaining it; meaning the individual customer that is committed believes the relationship is worth dying for to sustain it indefinitely". Can \& Wheale (2004) stated that higher levels of commitment are expected for relationship success meaning the level of commitment by both parties determines the short and long term achievement of the organizational goals. Commitment is generally regarded to be an important result of good relational interactions and is affected by the customer's perception of the effort made by the seller. The benefits derived from an existing relationship will serve as a catalyst to commitment. Liang \& Wong (2004) viewed commitment as an important variable in the measurement of customer loyalty. Differently stated, commitment exists through behavioural, attitudinal, affective and calculative components (Du Plessis, 2010:9495; Davis-Sramek, Mentzer \& Stank, 2008:443-445; Evanshitzky \& Plassman, 2006:63).

Research conducted by Mohr and Nevin (1990) highlighted the important role played by communication serving as conduit for connecting retailers and customers. Singh and Sirdeshmukh (2000) also stated that communication is an important strategy for establishing relationship with new customers and for improving the existing customers' relationship. Communication is needed as an urgent tool to initiate customer trust (Ring and Van De Ven, 1994). Mohammad Arabi and DavoodIzadi (2005) concluded that communication is a conscious or unconscious process of transferring feelings and opinions in form of message which is sent, received and perceived. Macintosh et al. (1992) defined communication as advertisement, sales force face to face connections, public Relation, packaging and any form that company send its products to external environment. Communications have these objectives of informing, persuading and remaining the customer about the company's product or service. Macintoth suggests a company without effective sales forces with strong communication does not have any chance to enhance the relationship with customers and persuade them for repurchasing.

Bonding can be traced from relationship management, which is closely related to good personal relations. It is considered to be one of the vital ingredients in establishing a long lasting relationship with a potential customer. Scholars in the field of marketing have different opinions as to what bonding is all about. It is seen as a business relationship that results in two parties (buyer and seller) acting in a unified manner towards a desired goal by Heide and John (1992). Similar opinion was shared by Wilson, (1995) where he viewed it as the 'the degree of mutual personal friendship and liking shared by the buyer and seller. Bonding 
customers using any of the integrated marketing communication stimuli enhances the company's chances of increasing its customer share. Bonding can be grouped into two categories: social bond and structural bond. Social bond has a number of dimensions including; social interaction, closeness, and friendship and performance satisfaction. Having a sound bonding scheme is proven empirically that it can lead to customer retention posited by Dominici and Guzzo (2010). Stated differently bonding can be attained using financial incentive by Berry and Parasuraman, (1991). He also argued that customers can be secured through bonding. Wilson (1995) and Reichheld (1993) concluded in their respective research that, building strong interpersonal bond among customers can lead to a greater percentage increase in customer retention.

The imperativeness of competence to the insurer cannot be overemphasized. To a large extent, it serves as an indicator whether the customer is ready to transact business with the company. Competence plays a key role in the "loyalisation" of a customer (Affran et al., 2019). Again, Affran et al (2019) stated that: 'Competence can be viewed as the quality or extent of being competent. It can emanate from formal or conscious skills acquired through years of experience on the job. Management is expected to exhibit these skills relationally in order to retain the customer they come in contact with. The individual customers dealing with the business entity should be assured with competence both in process and procedure'. Other scholars (Anderson and Weitz, 1992) viewed competence from technological point of view. How technology is applied to satisfy the customer's needs and wants. They categorized competence into four ways; (i) how the organization comprehend the consumer market. (ii) how they discharge their professional. (iii) How they help customers to plan their purchases. (iv) the ability to offer effective promotional materials. Customers remain unmovable and well committed when the organization displays a high sense of competence when discharging their economic responsibility. As posited by Aldlaigan and Buttle (2005) organizations competence is one of the underlying reasons why a customer becomes glued to a company's services.

\section{Methodology}

The study seeks to establish the linkage between relationship marketing strategies and customer loyalty with trust as the mediating variable. Three hundred insurance customers were purposively selected. They had certain characteristics; minimum age of 18 years, have been a customer at least for one half years, should have at least one policy with the insurance firm. Customers with these pedigrees undoubtedly have what it takes to establish this linkage. Self-administered questionnaires were used as a measurement tool to collect the data from period January to May 2019. The various items measuring the three underlying constructs were adapted from exiting literatures. A five-point Likert scale is used, ranging from "strongly disagree" (1) to "vigorously agree" (5). To examine the hypotheses, we used hierarchical regression analysis. Reliability and validity also were tested. Results show that items used in measuring were reliable and valid. Correlation analysis was also conducted to check relation among them. There was positive significant relationship among them.

\section{RESUlts AND Discussion}

TABLE I: SUMMARY DESCRIPTION OF CONSTRUCTS

\begin{tabular}{|c|c|c|c|c|}
\hline & Mean & Std. Deviation & Skewness & Kurtosis \\
\hline Commitment & 1.54 & .544 & .726 & 1.152 \\
\hline Communication & 1.65 & .533 & .934 & 1.213 \\
\hline Competence & 1.42 & .522 & .762 & .735 \\
\hline Bonding & 1.32 & .615 & 1.270 & -1.141 \\
\hline Trust & 1.66 & .722 & .763 & .135 \\
\hline Customer Loyalty & 1.74 & .556 & .737 & .234 \\
\hline Valid N (list wise) & & & & \\
\hline
\end{tabular}

A mean of 1.54 for commitment shows that the respondents agreed that commitment is key factor that explains relationship marketing in the insurance industry. Again, the mean mark of 1.65 for communication indicates that on the average a respondent within the study population agreed that they have good communication ability. Moreover, the mean mark of 1.42 for competence shows that respondents agreed that they are competent in what they do. Again, the mean mark of 1.32 for bonding suggests that the respondents understudy agreed to the fact that there is a good level of bonding among its customers. Also, the mean mark of 1.66 for trust implies that respondents agreed that their firm exhibits some level of trust for their customers. Lastly, the mean mark of 1.74 for customer loyalty shows that respondents agreed that loyalty is of key importance in their business.

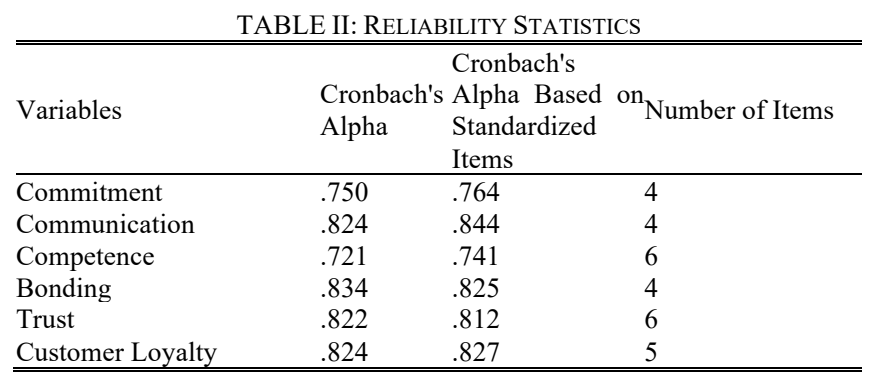

From Table II it can be seen that the Cronbach's Alpha of the entire variable namely: commitment, communication, competence, bonding, trust, and customer loyalty used in the study exceeded the conventional acceptable value of 0.70 . Thus, the items used in measuring the variables were accurate and reliable. Hence, it can be said that all the variables understudy has been verified to be reliable for the Pearson's product moment correlation analysis. The implication is that the statements used for the variables constitutes a complete structure in describing commitment, communication, competence, bonding, trust and customer loyalty.

\section{CORRELATION ANALYSIS}

The Pearson's product moment correlation analysis was used to establish the relationships among the s variables. 
The results revealed positive relationships among the variables in Table III.

\begin{tabular}{lllllll}
\multicolumn{7}{c}{ TABLE III: CORRELATION } \\
\hline 1 & Commitment & 1 & 2 & 3 & 4 & 5 \\
2 & Communication & - & & & & \\
3 & Competence & $.600^{* *}$ & - & & & \\
4 & Bonding & $.532^{* *}$ & $.466^{* *}$ & - & & \\
5 & Trust & $.533^{* *}$ & $.598^{* *}$ & $.461^{* *}$ & - & \\
6 & Customer Loyalty & $.442^{* *}$ & $.373^{* *}$ & $.568^{* *}$ & $.309^{* *}-$ \\
\hline
\end{tabular}

It can be seen from Table III that there is a positive significant relationship between commitment and trust $(\mathrm{r}=$ $.442, \mathrm{p}<0.01)$. Thus, the more the business entity increases its commitment to her customers the more trustworthy they become to their customers. Similarly, the results of the study pose a positive inclination between communication and trust; thus $(\mathrm{r}=.373, \mathrm{p}<0.01)$. The implication is that as the company commits its effort in communicating effectively and more efficiently to its customer base, the more trustworthy they become from the customer perspective. The situation is not different as in case of the relationship between competence and trust. $(\mathrm{r}=.568, \mathrm{p}<0.01)$. This presupposes that as firms become more competent in their service delivery the more they enhance their customer trust. Also, the results as per the correlation analysis, was proven that there is a positive relationship between bonding and trust thus $(r=309, p<0.01)$. Finally, it was also proven that there is an existing relationship between trust and customer loyalty. $(r=.595, \mathrm{p}<0.01)$. That is the company will begin to experience a corresponding incremental jump in its customer loyalty whenever trust increases proportionately.

TABLE IV: HIERARCHICAL REGRESSION ANALYSIS OF VARIABLES ON TRUST

\begin{tabular}{|c|c|c|c|c|c|c|}
\hline & \multicolumn{3}{|c|}{$\begin{array}{l}\text { Standardized } \\
\text { Coefficients }\end{array}$} & \multicolumn{2}{|c|}{$\begin{array}{l}\text { Co linearity } \\
\text { Statistics }\end{array}$} & $\mathrm{F}$ (Anova) \\
\hline (Constant) & & 3.534 & .001 & & & 78.762 \\
\hline RM & .214 & 1.735 & .104 & .563 & 1.877 & \\
\hline$\overline{\mathrm{RM}}$ & .709 & 15.727 & 7.000 & .678 & 2.338 & \\
\hline Trust & .494 & 10.06 & .000 & .544 & 1.786 & \\
\hline
\end{tabular}

Dependent Variable: Customer Loyalty

Dependent Variable: Trust

\section{Testing Hypothesis}

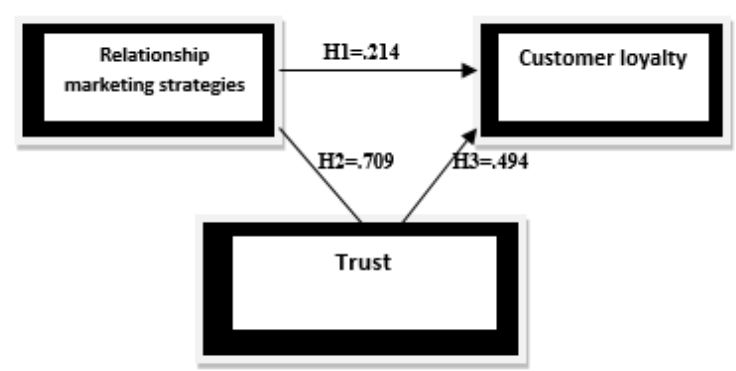

Fig. 1. Impact of Relationship Marketing Strategies on Customer Loyalty

Hypothesis 1- An organizational consciousness in relationship marketing strategies will influence customer loyalty positively.

Observing critically from Table IV conclusion can be drawn to the fact that there is a positive relationship between relationship marketing strategies and customer loyalty $\left(R^{2}=\right.$ $.214 \mathrm{p}<.114$ ) but the impact is quite insignificant within the Ghanaian insurance industry. In essence, holding all other variables constant, relationship marketing strategies induces $21.4 \%$ change in customer loyalty of the insurance companies understudy. Meaning a unit change in relationship marketing strategies will induce $21.4 \%$ change in customer loyalty. If managers of these firms decide to improve their relational strategies by $1 \%$, correspondently customer loyalty will increase by $21.4 \%$. The significance level of this outcome according to the study results was .104 shows that the impact was not significance because it's less than the traditionally accepted value (i.e. 0.05) for better significance. This is an indication that the variance between the two variables in question was insignificant. Better still hypothesis one was accepted.

\section{IMPACT OF RELATIONSHIP MARKETING STRATEGIES ON TRUST}

Hypothesis 2- An improvement in relational marketing strategies will increase customer trust for the insurance product tremendously.

Hypothesis two of the study was accepted because the results shows a positive inclination of relationship marketing strategies on trust; thus $\left(R^{2}=.709, \mathrm{p}<0.01\right)$ Thus, holding all other variables constant, relationship strategies causes $70.9 \%$ change in trust. This result proves that a unit change in the firms' relational strategies will induce $70.9 \%$ change in the trust the customers have for the insurance company. In other words, when the company focuses on improving its relationship strategies by $1 \%$, trust will also increase by $70.9 \%$. The significance level of this outcome in reference to the study results was 0.000 indicating that the variance between the two variables in question was significant.

\section{IMPACT OF RELATIONSHIP MARKETING STRATEGIES ON CUSTOMER LOYALTY THROUGH TRUST}

Hypothesis 3-An incremental adjustment in the insurance relational marketing strategies will have a significant positive influence on customer loyalty through trust.

As hypothesized earlier, that relationship marketing strategies will only have a significant influence on customer loyalty through trust, the results show same. The results in Table IV indicates that though there is a positive relationship between relationship marketing strategies on customer loyalty thus $\left(R^{2}=.214\right)$ but this impact is not significant as the significant level is 0.104 which is way above the standard significant value of 0.05 . But trust is seen as a full mediating variable as it's able to link relationship marketing strategies to customer loyalty $\left(\mathrm{R}^{2}=.494\right)$ with a perfect significant value of $(0.00)$. We can emphatically say that within the Ghanaian insurance industry for a firm to build loyal customers, first of all, they need to channel their entire relational strategy towards attaining customer trust. Therefore, trust is a critical ingredient in establishing customer loyalty within the insurance sector. 


\section{IMPLICATION}

Another foot has been chalked through this research. Additional knowledge has been added to the existing literature on the field of relationship marketing by proving empirically that truly communication, commitment, competence and bonding are relational marketing strategies in the insurance industry. The study also established the impact of trust on customer loyalty. It revealed that, trust impacted positively on relationship marketing and customer loyalty. Meaning, trust is the main potential force needed by firms wanting to achieve customer loyalty within the Ghanaian insurance industry. The practical connotation is that insurance companies wishing to attain customer loyalty should strategically engage its entire relationship marketing strategies in building the customer trust. To achieve this, the research revealed that managers of the insurance companies should be concerned with security of its customer transactions. The companies should fulfill all the promises they make to their customers when undertaking the insurance policy. The company should be consistent in providing quality insurance policies to all potential customers. Insurance brokers and other employees should show respect to customers when they insisting on their needs. Again they should fulfill their obligations promptly to customers especially when they are coming for their claims. The study once again revealed that trust in the insurance sector depends on the confidence the customer has in the company's insurance services. Communication, commitment, competence and bonding were individually proven to be empirically significant in achieving customer loyalty through trust in the Ghanaian insurance industry. It implied that, managers and staff of the insurance companies should be very tactical in focusing their relationship marketing strategies (Communication, commitment, competence and bonding) in achieving customer trust which will subsequently lead to customer loyalty. Recap from the finding revealed that trust is an unavoidable and a very necessary evil in the insurance industry if one wants to achieve customer loyalty.

\section{CONCLUSIONS AND FUTURE RESEARCH}

The insurance industry has been struggling extensively as to how to retain their hard won customers. This research has proven that within the insurance industry it is possible to maintain loyalty with customers through trust. This means that customer trust mediated perfectly between relationship marketing strategies and customer loyalty. The understanding is that, relationship marketing strategies (Communication, commitment, competence and bonding) can lead to customer loyalty if it is first tailored in achieving customer's trustworthiness. The results can be tested in other service industries and again in other advanced countries.

\section{REFERENCES}

Affran, S., Dza, M., \& Buckman, J. (2019). Empirical conceptualization of Customer loyalty on relationship marketing and sustained competitive advantage. Journal of Research in Marketing, 10(2), 798-806.
Almoraish, A., \& Gounaris, S. (2018, May). How does past and present customer experience explain the satisfaction with the supplier? A fuzzy set qualitative comparative approach. In European Marketing Academic Annual Conference: EMAC 2018.

Armstrong, G. M., Kotler, P., Harker, M. J., \& Brennan, R. (2018). Marketing: an introduction. Pearson UK.

Carlander, A., Gamble, A., Gärling, T., Johansson, L. O., Hauff, J. C., \& Holmen, M. (2018). The role of perceived quality of personal service in influencing trust and satisfaction with banks. Financial Services Review, 27(1).

Cénophat, S. (2018). Customer Relationship Vulnerability: A New Concept in Relationship Marketing.

Chang, H. C., Cheng, L. J., Tsai, Y. C., \& Lai, H. C. (2018). The Relationship between Relationship Investment, Relationship Quality, and Attachment Styles. Contemporary Management Research, 14(1).

Du Plessis, H., \& Oosthuizen, P. (2018). Construction project management through building contracts, a South African perspective. Acta Structilia, 25(1), 152-181.

Duggal, E., \& Verma, H. V. (2019). Relationship Quality and Customer Demographics in Indian Retail. In Dynamic Perspectives on Globalization and Sustainable Business in Asia (pp. 106-127). IGI Global.

Frankel, R., Mollenkopf, D. A., Russo, I., Coleman, B. J., \& Dapiran, G. P. (2016). What do we Really Know About What we Know? The Nature of Relationship Governance in the Reverse Supply Chain. In Looking Forward, Looking Back: Drawing on the Past to Shape the Future of Marketing (pp. 96-99). Springer, Cham.

Hajli, N., Sims, J., Zadeh, A. H., \& Richard, M. O. (2017). A social commerce investigation of the role of trust in a social networking site on purchase intentions. Journal of Business Research, 71, 133-141.

Hammick, J. K., \& Ju, I. (2018). Facebook fan page: the effect of perceived socialness in consumer-brand communication. Journal of Marketing Communications, 24(7), 686-702.

Holtom, B. C., \& Burch, T. C. (2016). A model of turnover-based disruption in customer services. Human Resource Management Review, 26(1), 25-36.

Koohang, A., Paliszkiewicz, J., \& Goluchowski, J. (2017). The impact of leadership on trust, knowledge management, and organizational performance: A research model. Industrial Management \& Data Systems, 117(3), 521-537.

Leonidou, L. C., Aykol, B., Fotiadis, T. A., Christodoulides, P., \& Zeriti, A. (2017). Betrayal in international buyer-seller relationships: Its drivers and performance implications. Journal of World Business, 52(1), 2844.

Levy, S., \& Hino, H. (2016). Emotional brand attachment: a factor in customer-bank relationships. International Journal of Bank Marketing, 34(2), 136-150.

Mindell, A. (2019). The Year 1: Global Process Work: Community Creation from Global Problems, Tensions and Myths. Gatekeeper Press.

Murphy, M., \& Sashi, C. M. (2018). Communication, interactivity, and satisfaction in B2B relationships. Industrial Marketing Management, $68,1-12$.

Rasheed, H. M. W., Khalid, J., Khizar, H. M. U., Sajid, M., Shahid, M. N., Ahmad, M., \& Khan, W. A. (2015). Factors affecting customer loyalty in banking sector: A study on banks in Bahawalpur (Pakistan). International Journal of Accounting and Financial Reporting, 5(1), 239-254.

Riquelme, I. P., Román, S., Cuestas, P. J., \& Iacobucci, D. (2019). The Dark Side of Good Reputation and Loyalty in Online Retailing: When Trust Leads to Retaliation through Price Unfairness. Journal of Interactive Marketing, 47, 35-52

Srivastava, M., \& Rai, A. K. (2018). Mechanics of engendering customer loyalty: A conceptual framework. IIMB management review, 30(3), 207-218.

Sutanto, J. E., \& Djati, S. P. (2017, July). Effect of Trust, Satisfaction, and Commitment on Customer Loyalty at the Alfamart Retail in Surabaya, East Java-Indonesia. In 2017 International Conference on Organizational Innovation (ICOI 2017). Atlantis Press.

Tidd, J., \& Bessant, J. R. (2018). Managing innovation: integrating technological, market and organizational change. John Wiley \& Sons.

Yao, T., Qiu, Q., \& Wei, Y. (2019). Retaining hotel employees as internal customers: Effect of organizational commitment on attitudinal and behavioral loyalty of employees. International Journal of Hospitality Management, 76, 1-8.

Yao, T., Qiu, Q., \& Wei, Y. (2019). Retaining hotel employees as internal customers: Effect of organizational commitment on attitudinal and behavioral loyalty of employees. International Journal of Hospitality Management, 76, 1-8. 